DOI: https://doi.org/10.30525/978-9934-26-020-9-9

Yurii Radionov

Doctor of Economic Sciences, Head of the International Standards Adaptation and Implementation Department

The Accounting Chamber of Ukraine (Kyiv)

\title{
BUDGET POLICY TO STIMULATE SOCIO-ECONOMIC DEVELOPMENT OF REGIONS
}

\section{Summary}

The system of regional development and the conceptual apparatus of the term «region» are analyzed. Modern problems of local budgets are revealed. The focus is on the low level of financial capacity of local budgets, which affects the state of solving current socio-economic problems, as well as the independence of local governments. At the same time, there are examples of inefficient use of budget funds, which are allowed by budget managers at the local level, which negatively affects the achievement of priority goals of socio-economic development of territories. Attention is focused on the need to improve the quality of management of managers and recipients of budget funds, including the use of program-targeted budgeting method. Emphasis was placed on the need to expand the tax capacity of the regions in filling local budget revenues. Emphasis is placed on the expediency of better use of budget policy instruments in improving the effectiveness of budget expenditures, ensuring sustainable dynamics of socio-economic development of regions, which will improve the level and quality of life.

\section{Introduction}

At this stage of social development, an important factor in building an independent, legal, democratic, socially oriented state is overcoming poverty, creating new jobs, building modern infrastructure, increasing gross regional product, ensuring a high level of socio-economic development and creating decent living conditions in to each settlement of the country.

In this relationship, the formation of an effective state mechanism for regional development, overcoming socio-economic disparities is growing in line with trends in economic development, threats associated with hostilities in eastern Ukraine, gaps in the economy, social policy, financial sector, the growth of other negative phenomena in society. Studies that ensure the unity of state policy in the formation and implementation of sustainable development of regions are becoming relevant. In addition, the modern country, as a closed economic space of subnational entities is losing relevance, but the role of regions is growing. It is important that the state regional policy meets the tasks that arise at the appropriate stage of social development, as a set of goals, priorities and objectives of the state, it must 
meet the strategy of socio-economic development in ensuring the welfare of the population, protection of constitutional rights and freedoms. It is possible to achieve these goals under the conditions of the appropriate level of financial resources, transparency of the local budget, reasonableness of the directions of use of budget expenditures, accountability and controllability of actions of local authorities.

The needs of communities are the basis for the formation of both regional and budgetary policies. The latter should stimulate the socio-economic development of the area, increase its economic and tax potential, ensure the growth of domestic sources of financial resources. Each country develops its own algorithm and uses effective tools for redistribution of budget resources between levels of the budget system to ensure the appropriate level of providing the population with quality public goods, social services, this determines the relevance of this study.

Researchers such as O.S. Vlasiuk [11], H.V. Vozniak [1], V.V. Voitovych [18], M.S. Yevtushenko [21], V.I. Yeleiko [9], A.Ya. Kuznetsova [8], Ye.Yu. Kuzkin [12], S.A. Romaniuk [2], N.V. Savchuk [10], O.A. Stashevskyi [5], N.B. Tatarin [18] and others. Their works focus on the problems of filling local budgets, addressing pressing regional socioeconomic issues, improving infrastructure, expanding the network of accessible social services to the population. However, today there are problems of a systemic approach to regional development, imperfection of the management model, uncertainty of strategic development prospects, low institutional and financial capacity of local authorities, insufficiently effective mechanism for generating local budget revenues, the need to overcome disparities in equalization of socio-economic development. low efficiency of budget funds use, etc. This is primarily due to the complex processes of interpenetration of contradictions of economic, social, political, natural, spatial, as well as the diverse structure of local government, heterogeneity of territories and their economic potential.

The purpose of the study is to generalize scientific approaches to the development of regions, identify problems of local budgets, increase the role of budget policy in stimulating the socio-economic development of territories.

\section{Part 1. The role of local budgets in establishing the independence of local governments and regional development}

The issue of formation and development of regions, their financial and economic component becomes especially relevant in the current conditions of economic transformation, as it directly affects the socio-economic condition of the country.

One of the key concepts in the study of theoretical approaches to regional development is the term «region». Methodological approaches to defining the essence of the concept of «region» and the problems of regional development are not constant, but evolve in the process of changing economic reality: from 
classical (where the region is the accumulation of natural resources, population, means of production, etc.) to modern theories (where the region is multifunctional system with an innovative vector of development) [1, p. 34-35].

According to Romaniuk S.A., the region is the largest administrativeterritorial unit of the subnational level, which has elected government, legal independence and its own budget [2, p. 3].

Some researchers rightly point out that the region as a subject of economic activity is defined as a territory characterized by common socio-economic, political and geographical factors, has its own territorial features, its own specifics, where there are unique economic and social conditions [3, p. 98].

According to H.V.Vozniak, being a subject of economic relations, and not only a carrier of natural, human, economic resources, in modern regionalism the region is considered as a multifunctional and multifaceted system. Regions are divided into territories to achieve a specific goal and to solve specific problems. The basis of economic division of regions may be the territorial division of labor, the tasks of administrative management or the need to address specific problems of socio-economic development of territories [1, p. 35].

In Ukraine, the concept of «region» is identified with the region, administrative or economic district. Thus, the Law of Ukraine «On Stimulating the Development of Regions» states that the region is the territory of the Autonomous Republic of Crimea, oblasts, cities of Kyiv and Sevastopol [4]. The law stipulates that stimulating the development of regions is a set of legal, organizational, scientific, financial and other measures aimed at achieving sustainable development of regions through a combination of economic, social and environmental interests at the national and regional levels, the most effective use of regional potential and the state as a whole [4].

It should be noted that the dynamics of sustainable development of regions is influenced by regional policy, which reflects the combination of a set of interests with the goals of socio-economic development of the state, its priorities, important social tasks. The region as a holistic, systemic formation is a complex network of special functions and goals, opportunities and limitations, development of industrial, agricultural, social, budgetary policy in a single territory. An effective socio-economic policy for the implementation of each region is to combine links with different territorial and administrative units, taking into account specific features and defining clear, priority tasks for its development.

In addition, the dynamics of regional development is influenced by the clear division of powers between the central executive power and local governments.

In the modern sense, local government began to take shape in the 18th-19th centuries. The first theories of self-government emerged, and certain provisions of municipal activity were defined at the legislative level. In particular, the fullest rights of local self-government are reflected in the 
Belgian Constitution (1831), according to which, along with the legislative, executive and judicial branches, the municipal [5, p. 87-88].

As one of the foundations of the constitutional order of Ukraine, local selfgovernment is the most important means of strengthening the state, establishing its independence, providing the foundations of economic power.

The starting point for building an effective institution of local selfgovernment capable of effectively performing functions at a new, high-quality level and ensuring sustainable dynamics of socio-economic development is the analysis of the nature of local self-government and the system of ensuring the powers of its bodies.

In different countries, there are sometimes formed different models, forms of local self-government, which mainly reflect the specifics of the territorial organization of the country.

Taking into account the specifics of the countries, significantly different models of local self-government were formed: Anglo-Saxon (English), continental (French) and «mixed» [5, p. 88].

In accordance with the principles of the European Charter, local selfgovernment is defined as the right and real ability of local self-government bodies to regulate a significant part of public affairs and manage it, acting within the law, under their responsibility and in the interests of the population [6].

The nature of formation is the basis for the formation of the substantive essence of local self-government, which is reflected in the specifics of the territorial administrative system and is a reflection of each model of the institution of local self-government.

The theory of local self-government formed by German researchers R. Gneist and A. Stein proceeds from the fact that community affairs are state affairs, because the state delegates its powers to territorial communities, and therefore there are no significant differences between the state and local government. On the contrary, the source of power of local self-government is the state, so the activities of the community, a separate territory meets the state interests. Local governments can ensure better and more effective implementation of state goals with the appropriate powers and financial resources that are transferred from the center to the regions.

The local budget is the basis of financial independence of local governments, and a good reason for its emergence is the need to provide citizens with certain public goods and services.

In economic essence, local budgets are an integral part of the budget system of the state, they outline economic relations between individuals, businesses and the territorial community, aimed at forming a fund for the needs of the community, improving the welfare of citizens, socio-economic development

According to Article 1 of the Law of Ukraine «On Local Self-Government in Ukraine», the local self-government budget (local budget) is a plan for the formation and use of financial resources necessary to ensure the functions and 
powers of local self-government [7]. According to Article 64 of the Law [7], formation of local budget expenditures is carried out in accordance with the division of expenditures between budgets, as defined by the Budget Code of Ukraine, to ensure the implementation of local governments of their powers. At the same time, the differentiation of types of expenditures between local budgets is formed on the basis of the principle of subsidiarity and their maximum approximation to the consumer of public goods and services.

Local budgets provide funds to finance activities and programs of socioeconomic development of the territory. The criterion for classifying the budget as «local» is not administrative territorial affiliation, but a form of self-organization of citizens, i.e. belonging to the relevant community.

Increasing the amount of financial resources in the local budget, including through the state budget, helps to expand the capacity of local authorities to address pressing socio-economic problems, leveling the economic and social development of settlements, improving the level and quality of life of citizens.

The share of GDP that is redistributed through local budgets indicates the level of centralization or decentralization. The experience of developed countries shows that the stronger the local government, the higher the level of welfare of the population.

According to most researchers, the current budget policy of Ukraine should be focused on expanding the network of affordable, high-quality public goods and services, so that every citizen, regardless of place of residence, receives them in sufficient quantity and quality.

Modern regional development policy should be based on a paradigm that takes into account the interests of the regions, the achievements of intersectoral cooperation, decentralization of power and balance (budgetary, economic, social, political). The development of the region, as a strategic goal of the state regional policy, is determined not only by economic growth, but, to a large extent, by the state budget policy [1, p. 41].

Regional policy, as an important component of the continuation of national economic policy, should promote the effective use of internal reserves of each district, region to increase the tax capacity of the area, increase local budget revenues.

The basis of the country's economic potential includes the financial one. The same can be said for the region. Financial potential characterizes both its socio-economic condition and ability to further develop [8, p. 23].

Current trends in the financial system have necessitated improving the management of financial resources, as in the economic, financial, political situation becomes relevant to optimize both state and local budgets, the introduction of proper budgeting, which will determine the relationship between vertical and horizontal levels and reflect the role in reforming the national economy and local governments.

The formation of a favorable macroeconomic environment, timely and sound decisions in the budget sphere, ensuring the stability of public finances, 
economic growth rates based on modernization of the economy, increasing its competitiveness, forming a medium-term budget with clear fiscal and expenditure guidelines requires scientific evidence.

The impact of budget expenditures as a component of budget policy is important in improving the welfare of the population, and therefore needs to be adjusted to take into account the impact of the dynamics of socio-economic processes. Their increase or decrease is one of the ways to regulate the rate of economic growth of territories and the country as a whole.

Budget expenditures require constant evaluation of the effectiveness of their use, as they are an important indicator of financial activity and development of the state and local self-government, an important factor in optimizing and improving the budget structure.

For the purpose of economic growth of territories, the primary task is to identify shortcomings and problems that negatively affect the sustainability of the socio-economic condition of administrative-territorial units, strengthening their budget potential using local resource reserves, primarily focusing on recreational, natural and other features is in this area.

The interests of the state and the region must be clearly delineated, have a clear hierarchical structure, and complement each other with appropriate sources of funding.

Local self-government in modern socio-economic conditions performs three functions: the function of power, economic function and the function of self-organization of citizens to address socio-economic issues. Therefore, it must have sufficient financial resources to fully perform the functions and tasks assigned to it. At the same time, there are discrepancies between the powers formally enshrined in current legislation and the necessary resource base and actual finances to provide state-guaranteed social services to the population, which causes significant cash gaps in the implementation of local budgets.

Prerequisite for the independence of local budgets is their real financial independence from the central government budget in the format of financing programs of socio-economic development of territories, realization of the right of fiscal initiative, exercise of a number of other constitutional powers in the field of management and resource potential [9, p. 84-85].

The effectiveness of the budget policy of local governments is determined primarily by the completeness of the implementation of the functions of local budgets. At the same time, it should be noted that the decisive influence on the quality of specific budget decisions in the field of local revenues and expenditures has a subjective factor - the availability of appropriate powers and competencies of local authorities. Thus, the problem of independence of local budgets is the primary prerequisite for an effective policy of formation and use of financial resources of local government, the key to achieving the financial priorities of local communities and their associations [9, p. 84]. 
The current problem of fiscal policy is the efficient and equitable redistribution of GDP between those regions that are stronger financially and those that do not have sufficient funds to address the pressing problems of the territory.

In developed, industrial regions, local budget revenues are much higher than, say, in depressed ones, which is reflected in the income of the population, economic development, and the provision of appropriate levels of social services to citizens. At the same time, the so-called «rich regions» usually do not want to share financial resources with those who are not sufficiently developed. In this situation, the stimulating function of economic development is lost, so it is important that fiscal policy is aimed at encouraging the growth of local budget revenues, so that regions increase the revenue base of local budgets from their own reserves by increasing the tax potential of the area.

Local taxes and fees are one of the important tax sources of local budget revenues. Effective measures need to be taken to use such tools to stimulate economic growth in order to interest local authorities in intensive economic development, thereby helping to increase local budget revenues.

Unfortunately, the current budget policy of Ukraine does not create the preconditions for proper socio-economic development in all regions of the country yet, which is reflected in the development of the whole country and living standards.

Implementing the budget policy, the state uses various financial instruments, levers and methods to significantly improve and influence the indicators of socio-economic development of its territories. Reducing the number of unproductive and inefficient budget expenditures contributes to the optimization of the expenditure side of local budgets, which affects the level of real economic growth of individual territories and the state as a whole.

\section{Part 2. Prospects of budget policy in stimulating regional development}

Budget policy as a component of financial and national economic policy should play an important role in the economic growth of regions, by stimulating local budgets to strengthen their financial potential. To assist in the implementation of the structural restructuring of the regional economy, to ensure current socio-economic transformations in accordance with the objectives and goals of the development strategy of each administrative territorial unit.

The application of the stimulus mechanism of budget policy in improving regional development should focus on increasing incomes, reviving business activity, improving the investment attractiveness of the region, expanding the tax base of all sectors of the regional economy, which should increase local budget revenues. 
Budget policy priorities play an important role in regulating the country's economic development and solving social problems. Budget priorities are the accumulation of taxes, the distribution of budget funds through the system of expenditures, the system of inter-budgetary relations, deficit financing and public borrowing policy [10, p. 59].

The growth of local budget revenues will increase the degree of financial independence of administrative territorial units, allow local governments to respond quickly and solve problems on the ground, increase budget expenditures on social protection and social security.

In modern conditions, there is an urgent need to strengthen the role of fiscal policy in promoting sustainable socio-economic development of regions, regulation of socio-economic processes, the principles of revenue generation and the use of budget expenditures. To analyze the existing natural and economic, demographic, recreational potential, clarify regional concepts of socio-economic development of territories, methods of stimulating and supporting local entrepreneurship, expanding opportunities for potential investors.

Sustainable socio-economic development of regions depends on the effectiveness of regional, including budgetary policy, the use of mechanisms to stimulate budgetary development of regions, priorities and needs of the local community.

The dynamism of socio-economic development requires the identification of possible risks, significant shortcomings, clarification and adjustment of indicators, as well as the improvement of budget legislation as an important element of budget policy in ensuring the sustainable development of regions.

Effective state regional policy should be based on effective budget planning, financial equalization of regions on objective criteria, so that each administrative territorial unit has the opportunity to implement its own regional policy taking into account national interests, as well as the ability to raise social standards.

According to Vlasiuk O.S., regional policy should minimize regional disparities and prevent the emergence of depressed territories and regions with economies, so its priority is to restore the positive economic dynamics of regional development and strengthen interregional ties [11, p. 5-6].

In our opinion, one of the ways to overcome the existing disparities in the socio-economic development of the regions is to complete the reform of local self-government.

Reforming the system of local self-government in accordance with the provisions of fiscal decentralization is a difficult task, as it is impossible to redistribute powers, responsibilities and financial resources between levels of government without examining the ability to exercise these powers [12, p. 3].

The most important source of financial resources of local governments is the revenue of local budgets, which are formed through the rational management of their own and fixed sources of revenue. The main sources of 
local budget revenues include taxes (national deductions and taxes provided by law for local budgets, as well as local taxes and fees), funds of enterprises and organizations established by municipalities, local loans and funds for services provided by local governments. The ratio of these sources in the structure of local budgets determines the degree of their independence.

The instability of revenue sources and lack of funds affect the filling of local budget revenues. As a result, local governments cannot fully solve the problems of the local community, ensure the improvement of settlements, improve conditions in the field of health care, education, compliance with the proper condition of roads, a set of measures for socio-economic development.

Limited financial resources affect the level of unemployment in the regions, exacerbation of inflation, declining socio-economic development, the devaluation of the hryvnia and more.

The solution to the problem of lack of funds in local budgets is compensated by the share of inter-budget transfers in the revenues of local budgets, which are transferred from the state budget to local budgets.

Thus, on January 1, 2015, the Law of Ukraine of December 28, 2014 № 79 «On Amendments to the Budget Code of Ukraine on the Reform of Intergovernmental Relations» came into force [13], which changed the budgetary relations of state and local budgets and introduced a new type of intergovernmental transfer - the basic subsidy. The state budget and the budgets of the united territorial communities have been brought to direct inter-budgetary relations. The provision of new types of subventions educational and medical - has been introduced.

It can already be noted that the results of the decentralization reform launched in 2015 provided local governments with fiscal tools to increase their own financial resources and to some extent reduced their dependence on the central government in the financial sector. Funding for delegated powers has increased significantly. However, today most territorial communities are unable to independently exercise all their own statutory and delegated powers.

The reason for this state is the general instability of the system of intergovernmental relations, which does not perform its basic functions [14].

The results of audits conducted by the Accounting Chamber in 2016-2017 on the provision and use of certain intergovernmental transfers, showed the existence of unresolved issues regarding the reasonable definition of transfers, their legal and effective use. Thus, in 2016-2017, 1,017 local budgets received transfers (grants, subventions) from the state budget, including 24 regional budgets, 149 budgets of cities of regional significance and the budget of Kyiv, 456 district budgets, 388 budgets of united territorial communities. The total amount of resources transferred from the state budget to these budgets in the form of transfers amounted to 196 and 273 billion UAH, respectively, or one third of the state budget expenditures [15].

In 2019, transfers from the state budget to local budgets in the amount of 260 billion UAH, or 95 percent, were provided according to the plan for the 
year, of which 84 percent aimed at remuneration and other current expenditures of educational and health care institutions, the provision of benefits, housing subsidies and various types of assistance to certain categories of citizens [16].

Our analysis showed a relatively high share of expenditures in the social sphere, which characterizes the current guidelines of budget policy.

The experience of developed European countries proves significant advantages of economic development in comparison with the similar situation in Ukraine. The reason, in our opinion, is, inter alia, a fairly high level of efficiency and effectiveness of the use of budget funds and, accordingly, the achievement of appropriate indicators of socio-economic development.

In Ukraine, the situation is somewhat different, as evidenced by the results of audits, there is inefficient use of budget funds.

Thus, the audit of the effectiveness of the use of subvention funds from the state budget to local budgets for the formation of infrastructure of united territorial communities found that in 2017-2018, 3,294.9 million UAH of subvention from 3,400.0 million UAH allocated from the state budget was disbursed. An audit conducted in 13 oblasts at 37 audit facilities - the main managers and recipients of subvention funds at the local level (local councils, their structural units, utilities) with cash expenditures in the amount of 333.1 million UAH, established the facts of using funds in violation legislation in the amount of 21.1 million UAH (including damage to the state in the amount of 1.4 million $\mathrm{UAH}$ ), inefficient use -16.0 million $\mathrm{UAH}$, as well as violations of legislation on urban planning, public procurement and accounting for a total of 144.2 million UAH. The results of the audit showed the lack of a unified state policy of regional development and construction, which leads to an imbalance of budget policy in the relevant area and proper coordination of actions of managers and recipients of budget funds at the local level [17, p. 181].

According to the results of the audit of the effectiveness of the use of subvention funds from the state budget to local budgets to provide quality, modern and affordable general secondary education «New Ukrainian School», it is established that the state lacks a clear list of teaching aids and equipment to be purchased under the subvention. According to the results of the audit, it was established that the subvention funds were used inefficiently in the amount of 2.4 million UAH, uneconomically - 4.9 million UAH, unproductively - 416.7 thousand $\mathrm{UAH}$, inefficient management of the subvention funds in the amount of 387.9 thousand UAH was carried out inefficiently [17, p. 187].

There are many such examples, which show that inefficient management and use of budget funds, unfortunately, is one of the problems of the budget system, which negatively affects the effectiveness of fiscal policy.

In this situation, it is expedient to apply the program-targeted budgeting method more widely, so that budget expenditures are directed to strategic directions of regional development, clearly delineated for local self- 
government and state-delegated powers, and the role of regions as subjects of state budget policy needs to be strengthened.

Among a number of existing problems, for most regions the issue of improving transport services in cities, district and regional centers, improving the public transport system, balancing the interests of carriers and passengers and, accordingly, increasing the amount of budget funds for these purposes remains relevant.

The creation of municipal enterprises is one of the ways to expand the revenue base of the local budget, especially in such areas as information and communication technologies, rural and industrial tourism. In addition, it is important to optimize the structure of local budgets, both in terms of revenues and expenditures, as this is a powerful lever of influence on the economy and social development of the region. Optimization is a tool for overcoming the budget deficit, which is extremely important for local self-government.

In the current environment, it is crucial to complete budget decentralization in order to strengthen the independence and financial autonomy of local governments.

The state of socio-economic development of Ukraine requires strengthening the role of local governments in the integrated development of territories; search for effective tools for managing budget funds, improving methods of using financial resources. Financial decentralization is one of the important conditions for ensuring the viability of local governments, as it increases the opportunities and impact on the development of the controlled area, better performance, more careful coordination of expenditures with local needs and preferences.

Local budgets occupy not only an important place in the budget system, but also one of the central places in the economic system of each state, their role and importance are directly determined by the type of economic system, selected goals and priorities of social development [18, p. 161].

Diversity of local budgets is financial stability and economic development, a source of financial resources for the maintenance and development of municipal economy, a significant lever of financial equalization of territories, a factor in the financial base of local government in guaranteed state social benefits, improving welfare, macroeconomic regulation.

Effective socio-economic development of the regions is objectively limited by the level of its provision with financial resources, which are based on local budget revenues. In this context, the process of budget decentralization is especially important, as reforms in the budget sphere are designed to create economic incentives for local governments to develop their territories, expand their tax base and efficient use of budget funds [19, p. 261].

Given the best practices of European countries, in Ukraine there is a need to develop a multilevel system of targeted comprehensive programs for the development of natural and recreational areas, as they are a powerful tool for activating the reserves of economic and social growth of regions. Their 
implementation will help to solve regional problems caused by financial difficulties. Improvement of development programs for natural and recreational areas will provide the necessary guidelines to identify dominant trends, indicative quantitative parameters of socio-economic and environmental development, its place in the interregional division of labor, to identify and adjust the projected dynamics of national and regional markets own regulatory and influence social processes [20, p. 140].

The implementation of an effective budget policy involves enabling local governments to pursue their own socio-economic policies, taking into account the interests of the community in order to achieve certain priority goals of regional development.

Rationalization of budget policy should ensure the balance of private interests, the state, regions and, on this basis, to promote socio-economic development of territories, which will ensure its efficiency and effectiveness, to meet the demands of residents of individual territories.

Achieving a high level of economic and social development of the regions should be a priority of the economic policy of the state. At the same time, it is important to regulate between the center and the regions the issues of management of natural resources, property and finances in the respective territory, so that local authorities take greater responsibility for the socioeconomic development of the regions.

According to some researchers, it is a very difficult task to identify the priorities of local programs because it is related to the preferences of the community. The priorities of the population may not coincide with the national and normative ones. In this case, compliance with certain rules and instructions does not provide a positive result and contradicts the basic principle of public expenditure management - consumer orientation. In practice, any mechanisms for assessing the priorities of individual expenditures remain imperfect [21, p. 71-72].

Therefore, knowledge and professionalism are necessary for the formation and achievement of the set goals of local governments through the rational use of resources. However, in order to optimize the effectiveness of participation in the joint solution of the problems of the regions, which provides for the growth of local economic development, the process of making managerial decisions is important [22, p. 49].

Through effective budget regulation, the state, using leverage and appropriate tools, should help local authorities to develop socio-economic processes in the regions more effectively. After all, in the regional context, regional and state interests are combined in state and regional economic policy. The direction of socio-economic development of the city, district, region must meet national goals. The state is interested in the effective development of its territories, as it will help to raise living standards in the country. Therefore, the relationship between the state and the regions should 
be harmonized, complementary, optimally harmonizing the principles of centralization and decentralization.

An important factor that will contribute to effective regional development is a fair fiscal policy of the state with clear and understandable rules of the game to ensure the regions an adequate level of financial independence, based on its actual tax capacity. An integrated approach will ensure sustainable dynamics of development, while inconsistency threatens fragmentation, halfmeasures, chaos, low efficiency. We can say that without proven system solutions it is difficult to imagine the integral stable and dynamic development of the region [3, p. 98].

The priority goals of regional development will be successfully realized under the conditions of stimulating role of budgets, improvement of budgetary policy which will consider needs of a society, will promote activization of business activity. The main task of modern regional policy, as well as budget policy is to increase the financial capacity of local budgets, ensuring the provision of social services and public goods guaranteed by the Constitution and other laws of Ukraine.

A number of current socio-economic problems facing our country are the result of imperfect regional policy, as their solution lies in the ability of local governments to pursue effective regional policies that can solve complex economic, social, environmental and other problems.

It is necessary to strengthen control over the effective use of budget funds, as well as the responsibility of the main managers of budget funds for the formation and implementation of budgets. Budget legislation should be focused on the fight against corruption, punishment for any deviations from non-compliance with targets.

The implementation of the tasks of socio-economic development of the regions requires a change in the system of public administration, improvement of inter-budgetary relations and reform of the entire budget system. Without this, it is impossible to ensure a fair redistribution of GDP, increase the efficiency and quality of public and social services [23, p. 230].

Solving the problems of employment, efficient use of natural, recreational, financial and other resources, the ability of local authorities to create conditions for increasing production, growth of gross regional product and per capita income, affects the level of welfare of citizens. The state using financial levers and other economic instruments should stimulate socioeconomic processes in the regions, promote positive dynamics of economic growth.

\section{Conclusions}

The study has shown that the problems of regional development are not permanent, but change in the process of evolution of society and the emergence of a new economic reality. In modern conditions, regional development is an important factor in ensuring the sustainable dynamics of 
socio-economic development of the country, so this issue should be given due attention by a wide range of researchers to provide scientific support for the processes taking place in regional studies.

Modern regional policy should be based on effective budget planning, financial equalization of regions on objective criteria, so that each administrative-territorial unit has the opportunity to implement its own regional policy, taking into account national interests, as well as the opportunity to raise social living standards. As an important component of the continuation of national economic policy, regional policy should promote the effective use of internal reserves of each district, region to increase the tax capacity of the area, increase local budget revenues.

The problems of filling local budgets with financial resources should be solved by the reform of local self-government bodies, which began in Ukraine in 2015. At the same time, local governments must learn to effectively use local reserves for the development of regions, create new enterprises in the field of information and communication technologies, develop rural and industrial tourism, optimize the local budget structure, manage and use budget funds in priority areas of socio-economic development. territories, using, inter alia, the program-target method of budgeting.

The issue of efficiency of management and use of budget funds was and remains relevant for budget policy and the budget system of Ukraine in general, especially in the current conditions of limited financial resources, so it is necessary to improve methods of improving the efficiency of budget funds. In addition, it is advisable to use budget policy instruments more effectively in overcoming the existing disparities and stimulating the socioeconomic development of the regions in order to achieve better performance and improve the living standards of people in each locality.

\section{References:}

1. Vozniak H.V. (2015) Regionalnyi rozvytok; sutnist i metodolohichna osnova [Regional development; essence and methodological basis]. Regional economy, № 3, pp. 34-43.

2. Romaniuk S.A. (2001) Polityka rehionalnoho rozvytku v Ukraini; suchasnyi stan $i$ novi mozhlyvosti [Regional Development Policy in Ukraine: Current Status and New Opportunities]. Kyiv: UDAU. (in Ukrainian)

3. Lashuk O.S. (2018) Teoretyko-metodolohichni osnovy derzhavnoho upravlinnia rozvytkom rehioniv [Theoretical and methodological foundations of state management of regional development]. Scientific notes of TNU named after V.I. Vernadsky, vol. 29(68), no. 1, pp. 97-101.

4. Verkhovna Rada of Ukraine (2005) Zakon Ukrainy vid 08.09.2005 r. № 2850-IV «Pro stymuliuvannia rozvytku rehioniv» [Law of Ukraine of September 8, 2005 № 2850-IV «On stimulating the development of regions»]. Available at: https://zakon.rada.gov.ua/laws/show/2850-15\#Text (accessed 19 November 2020).

5. Stashevskyi O.A. (2014) Poniattiaa systemy finansovoho zabezpechennia povnovazhen orhaniv mistsevoho samovriaduvannia $\mathrm{V}$ suchasnykh sotsialnoekonomichnykh umovakh [The concept of a system of financial support for the powers of 
local governments in modern socio-economic conditions]. Scientific works of NDFI, issue 4(69), pp. 87-97.

6. Yevropeiska Khartiia mistsevoho samovriaduvannia vid 15.10.1985 roku (1985) [European Charter of Local Self-Government of 15.10.1985]. Available at: http://zakon3.rada.gov.ua/laws/show/994_036 (accessed 18 November 2020).

7. Verkhovna Rada of Ukraine (1997) Zakon Ukrainy «Pro mistseve samovriaduvannia v Ukraini» vid 21.05.1997 r. № 280/97-BP [Law of Ukraine «On local self-government in Ukraine» of 21.05.1997 № 280/97-BP]. Available at: http://zakon2.rada.gov.ua/laws/show/ 280/97-\%D0\%B2\%D1\%80 (accessed 19 November 2020).

8. Kuznetsova A.Ya., Kaspruk Yu.V., Kuznetsov O.Yu. (2013) Ekonomichnyi rozvytok rehionu ta rol mistsevykh biudzhetiv u yoho zabezpechenni [Economic development of the region and the role of local budgets in its provision]. Kyiv. (in Ukrainian)

9. Yeleiko V.I., Anisimov V.A. (2017) Biudzhetna polityka v umovakh detsentralizatsii biudzhetnykh vidnosyn [Budget policy in terms of decentralization of budget relations]. Development of the economy of Ukraine: transformations and innovations. Zaporizhzhia: Helvetica Publishing House, vol. 1, pp. 83-100.

10. Savchuk N.V. (2014) Biudzhetni prioritety Ukrainy u konteksti suspilnoho vyboru [Budget priorities of Ukraine in the context of public choice]. Kyiv: KNEU. (in Ukrainian)

11. Vlasiuk O.S. (2015) Problemy ta prioritety derzhavnoi rehionalnoi polityky u sotsialno-ekonomichnii sferi [Problems and priorities of the state regional policy in the socio-economic sphere]. Socio-economic problems of the modern period of Ukraine, issue 1(111), pp. 3-9.

12. Kuzkin Ye.Yu. (2014) Teoretychni aspekty fiskalnoi detsentralizatsii [Theoretical aspects of fiscal decentralization]. Scientific works of NDFI, issue 4(69), pp. 3-12.

13. Verkhovna Rada of Ukraine (2014) Zakon Ukrainy vid 28.12.2014 № 79-VIII «Pro vnesennia zmin do Biudzhetnoho kodeksu Ukrainy shchodo reformy mizhbiudzhetnykh vidnosyn» [Law of Ukraine of 28.12.2014 № 79-VIII «On Amendments to the Budget Code of Ukraine on the Reform of Intergovernmental Relations»]. Available at: https://zakon.rada.gov.ua/laws/show/79-19\#Text (accessed 21 November 2020).

14. Cabinet of Ministers of Ukraine (2017) Rozporiadzhennia Kabinetu Ministriv Ukrainy vid 08.02.2017 № 142-r «Pro skhvalennia Stratehii reformuvannia systemy upravlinnia derzhavnymy finansamy na 2017-2020 roky [Order of the Cabinet of Ministers of Ukraine dated 08.02.2017 № 142-r «On approval of the Strategy for reforming the public finance management system for 2017-2020»]. Available at: https://zakon.rada.gov.ua/ laws/show/142-2017-\%D1\%80\#Text (accessed 16 November 2020).

15. Accounting Chamber of Ukraine (2018), Zvit pro rezultaty analizu formuvannia ta vykorystannia mizhbiudzhetnykh transfertiv z Derzhavnoho biudzhetu Ukrainy mistsevym biudzhetam u 2016-2017 rokah [Report on the results of the analysis of the formation and use of intergovernmental transfers from the State Budget of Ukraine to local budgets in 2016-2017]. Available at: https://rp.gov.ua/upload-files/Activity/Collegium/2018/111_2018/Zvit_11-1_2018.pdf (accessed 15 November 2020).

16. Accounting Chamber of Ukraine (2020) Vysnovky pro rezultaty analizu richnoho zvitu pro vykonannia Zakonu Ukrainy «Pro Derzhavnyi biudzhet Ukrainy na 2019 rik» [Conclusions on the results of the analysis of the annual report on the implementation of the Law of Ukraine «On the State Budget of Ukraine for 2019»]. Available at: https://rp.gov.ua/upload-files/Activity/Collegium/2020/9-1_2020/Vysn_9-1_2020.pdf (accessed 10 November 2020).

17. Accounting Chamber of Ukraine (2020) Zvit Rakhunkovoi palaty za 2019 rik [Report of the Accounting Chamber of Ukraine for 2019]. Available at: https://rp.gov.ua/ Activity/Reports/?id=876 (accessed 13 October 2020). 
18. Tatarin N.B., Voitovych V.V. (2017) Mistsevi biudzhety yak finansova baza mistsevoho samovriaduvannia [Local budgets as a financial base of local self-government]. Scientific Bulletin of Uzhhorod National University. Series «International Economic Relations and the World Economy», issue 11, pp. 159-162.

19. Zaslavska O.I., Ohorodnik O.V. (2017) Finansova detsentralizatsiia v Ukraini: stan, problemy ta perspektyvy rozvytku [Financial decentralization in Ukraine: state, problems and prospects of development]. Collection of scientific works of Uzhhorod University, series «Economics», vol. 2(50), pp. 261-266.

20. Chychkaliuk T.O. (2016) Yevropeiskyi dosvid vykorystannia pryrodnorekreatsiinykh terytorii dlia rozvytku turyzmu [European experience in the use of natural and recreational areas for tourism development]. Bulletin of Odessa National University. «Economy» series, vol. 21, issue 2, pp. 138-141.

21. Yevtushenko M.S. (2016) Metodolohichni pidkhody do planuvannia vydatkiv mistsevykh biudzhetiv: zarubizhnyi ta vitchyznianyi dosvid [Methodological approaches to planning local budget expenditures: foreign and domestic experience]. Scientific works of NDFI, issue 1(74), pp. 68-82.

22. Barabash T.H. (2016) Finansovi peredumovy obiednannia ta spivrobitnytstva teritorialnykh hromad v Ukraini [Financial preconditions of association and cooperation of territorial communities in Ukraine]. Scientific works of NDFI, issue 2(67), pp. 44-52.

23. Radionov Yu.D. (2019) Formuvannia vydatkiv biudzhetu [Formation of budget expenditures]. Kyiv: KNTEU. (in Ukrainian) 